\title{
Magneto-structural properties of Ni-Zn nanoferrites synthesized by the low-temperature auto-combustion method
}

\author{
C O EHI-EROMOSELE ${ }^{1, *}$, B I ITA ${ }^{1,2}$, E EJ IWEALA ${ }^{3}$, S A ADALIKWU ${ }^{2}$ and P A L ANAWE ${ }^{4}$ \\ ${ }^{1}$ Department of Chemistry, Covenant University, PMB 1023, Ota, Nigeria \\ ${ }^{2}$ Department of Pure and Applied Chemistry, University of Calabar, Calabar, Nigeria \\ ${ }^{3}$ Department of Biological Sciences, Covenant University, PMB 1023, Ota, Nigeria \\ ${ }^{4}$ Department of Petroleum Engineering, Covenant University, PMB 1023, Ota, Nigeria
}

MS received 9 April 2015; accepted 1 June 2015

\begin{abstract}
Using nickel, zinc and ferric nitrates, and glycine in a fuel-rich composition, $\mathrm{Ni}_{1-x} \mathrm{Zn}_{x} \mathrm{Fe}_{2} \mathrm{O}_{4}$ nanoparticles were prepared by a simple low-temperature auto-combustion method without further sintering at high temperatures. The auto-combusted powders obtained were characterized by X-ray diffraction (XRD), Raman spectroscopy, scanning electron microscopy, energy-dispersive X-ray (EDAX) analysis and vibrating scanning magnetometer measurements. XRD confirms the formation of pure nanocrystalline spinel phases with an average diameter of about $55 \mathrm{~nm}$. Raman spectra show tetrahedral and octahedral sites in the structure of $\mathrm{Ni}_{1-x} \mathrm{Zn}_{x} \mathrm{Fe}_{2} \mathrm{O}_{4}$ and also imply the doping of $\mathrm{Zn}^{2+}$ and displacement of $\mathrm{Fe}^{3+}$ ions from the tetrahedral site. EDAX showed that the samples were close to the nominal compositions. The magnetic measurement shows that the saturation magnetization and remanence magnetization decreases with the increase in the zinc content.
\end{abstract}

Keywords. Ni-Zn ferrites; fuel-rich composition; combustion synthesis; Raman studies; magnetism.

\section{Introduction}

Nanocrystalline spinel ferrites with the common formula $\mathrm{AFe}_{2} \mathrm{O}_{4}(\mathrm{~A}=$ divalent metal ion, e.g., $\mathrm{Ni}, \mathrm{Zn}, \mathrm{Mn}, \mathrm{Co}$, $\mathrm{Mg}, \mathrm{Cu}$, etc.) are the most significant magnetic materials. ${ }^{1}$ In recent years, this class of magnetic nanomaterials has elicited many interests because of their fascinating electronic, magnetic, catalytic and biomedical applications. The interest for using these materials permanently increases because of their usability under extreme conditions. ${ }^{2}$ Nickel ferrite has been intensively investigated as one of the magnetic nanomaterials. ${ }^{3-6}$ Magnetic properties of ferrites can be changed by substituting various kinds of $\mathrm{A}^{2+}\left(\mathrm{Zn}^{2+}, \mathrm{Mg}^{2+}, \mathrm{Mn}^{2+}, \mathrm{Ni}^{2+}, \mathrm{Co}^{2+}\right.$, $\mathrm{Fe}^{2+}$, etc.) among divalent cations by introducing a relatively small amount of transition metal ions. ${ }^{7}$ The substitution of metal ions like $\mathrm{Zn}^{2+}$ into nickel ferrite has been proposed by many researchers to modify the electrical and magnetic properties. In particular, extensive studies of $\mathrm{Zn}$-doped $\mathrm{NiFe}_{2} \mathrm{O}_{4}$ have been conducted, which showed that the substitution of $\mathrm{Zn}$ for $\mathrm{Fe}$ decreases the Curie temperature and magnetic anisotropy ${ }^{8-11}$ and the substitution of $\mathrm{Zn}$ for $\mathrm{Ni}$ affects the electrical properties. ${ }^{9,11,12}$

\footnotetext{
*Author for correspondence

(cyril.ehi-eromosele@covenantuniversity.edu.ng)
}

Nickel-zinc ferrites are magnetic materials of much technological importance due to their high electrical resistivity, low magnetic coercivity and low eddy current losses. These properties depend upon the composition, microstructure and heat treatment of the samples. ${ }^{13}$ It is well known that properties of ferrite materials strongly depend on the preparation conditions. Many methods such as the citric acid combustion method, ${ }^{9,10,11,14}$ ureaassisted auto-combustion method, ${ }^{15}$ reverse micelles, ${ }^{8}$ hydrothermal method, ${ }^{16}$ co-precipitation method, ${ }^{17}$ solidstate method, ${ }^{18}$ etc., have been developed to prepare nanocrystallite nickel-zinc ferrite. The spinel ferrite particles synthesized by solid-state methods show an assembly of irregular shapes and agglomerations, ${ }^{19}$ while those prepared by most wet chemical methods require careful control of $\mathrm{pH}$ of the solution, concentration like parameters and high sintering temperature for the formation of particles. High-temperature synthesis of nickel-zinc ferrite may result in the evapouration of some of the constituents resulting in non-stoichiometry, and zinc volatilization and increased sintering temperatures can result in the formation of $\mathrm{Fe}^{2+}$ ions, thereby increasing the electron hopping and reducing the resistivity. ${ }^{11}$ Therefore, a method that requires low-temperature synthesis will be most suitable for the synthesis of nickel-zinc ferrite. Among the various methods for synthesizing ferrites, the combustion method stands out as an alternative and highly promising method. ${ }^{20}$ This method has additional 
advantages of simple preparation, formation of products with virtually any size or shape, and formation of highpurity homogeneous products. In combustion synthesis, the nature of fuel and fuel to oxidizer (metal nitrates) ratio can be used to tune the morphology, phase and magnetic properties of the final product.

In most auto-combustion processes, glycine as a fuel is preferred because of its high negative combustion heat $\left(-3.24 \mathrm{kcal} \mathrm{g}^{-1}\right)$ as compared to urea $\left(-2.98 \mathrm{kcal} \mathrm{g}^{-1}\right)$ and citric acid $\left(-2.76 \mathrm{kcal} \mathrm{g}^{-1}\right)$; hence, high sintering temperature is usually not required unlike with the other fuels. Also, glycine is readily available, economic and highly soluble in water. In our previous study on the combustion synthesis of cobalt-magnesium ferrite using different glycine metal nitrate ratio, a fuel-rich composition was found to produce the purest nanocrystalline ferrite with the highest saturation magnetization with no further sintering temperature compared with the fuel lean and fuel stoichiometric samples. Therefore, in the synthesis of the different compositions of $\mathrm{Ni}_{1-x} \mathrm{Zn}_{x} \mathrm{Fe}_{2} \mathrm{O}_{4}(x=0.65,0.7$ and 0.75$)$ using glycine as a fuel, fuel-rich composition is used $(\mathrm{G} / \mathrm{N}=$ 2.22). X-ray diffraction (XRD), Raman spectroscopy, scanning electron microscopy (SEM), energy-dispersive $\mathrm{X}$-ray (EDAX) analysis and vibrating scanning magnetometer (VSM) techniques are used to study the structural, morphological, chemical composition and magnetic properties of as-synthesized Ni-Zn ferrite MNPs, respectively.

\section{Experimental}

\subsection{Materials}

All the reagents are of analytical grade and are used as-received without further purification. Nickel nitrate $\left[\mathrm{Ni}\left(\mathrm{NO}_{3}\right)_{2} \cdot 6 \mathrm{H}_{2} \mathrm{O}\right]$, zinc nitrate $\left[\mathrm{Zn}\left(\mathrm{NO}_{3}\right)_{2} \cdot 6 \mathrm{H}_{2} \mathrm{O}\right]$ and iron nitrate $\left[\mathrm{Fe}\left(\mathrm{NO}_{3}\right)_{3} \cdot 9 \mathrm{H}_{2} \mathrm{O}\right]$ obtained from Sigma Aldrich, Germany, are taken as oxidants, while glycine $(\mathrm{G}$, $\mathrm{C}_{2} \mathrm{H}_{5} \mathrm{NO}_{2}$ ) obtained from SD Fine Chem. Ltd., Mumbai, was employed as fuel to drive the combustion process.

\subsection{Synthesis}

The $\mathrm{Ni}_{1-x} \mathrm{Zn}_{x} \mathrm{Fe}_{2} \mathrm{O}_{4}(x=0.65,0.7$ and 0.75$)$ ferrite is prepared by the low-temperature auto-combustion method. The amount of fuel used was calculated to be more than the stoichiometric amounts required for completion of the combustion process without heat exchange. Here, the glycine to nitrate ratio was $\mathrm{G} / \mathrm{N}=2.22$ (fuel-rich composition). For $x=0.65$ sample, $1.02 \mathrm{~g} \mathrm{Ni}\left(\mathrm{NO}_{3}\right)_{2} \cdot 6 \mathrm{H}_{2} \mathrm{O}$, $1.93 \mathrm{~g} \mathrm{Zn}\left(\mathrm{NO}_{3}\right)_{2} \cdot 6 \mathrm{H}_{2} \mathrm{O}, 8.08 \mathrm{~g} \mathrm{Fe}\left(\mathrm{NO}_{3}\right)_{3} \cdot 9 \mathrm{H}_{2} \mathrm{O}$ and $5.0 \mathrm{~g}$ glycine were dissolved in $20 \mathrm{ml}$ of distilled water and the solutions were heated to $80^{\circ} \mathrm{C}$ to form a viscuous gel of precursors under magnetic stirring. Secondly, the gel is transferred to a pre-heated coil $\left(300^{\circ} \mathrm{C}\right)$. Finally, after a short moment, the solution precursors boiled, swelled, evolved a large amount of gases and ignited, followed by the yielding of puffy black products. The powder (autocombustion powder) was heated in a hot air oven at $200^{\circ} \mathrm{C}$ for about $12 \mathrm{~h}$ to remove any organic product or unreacted glycine. Similarly, for $x=0.7$ sample, same procedures were followed except that $0.87 \mathrm{~g} \mathrm{Ni}\left(\mathrm{NO}_{3}\right)_{2}$. $6 \mathrm{H}_{2} \mathrm{O}$ and $2.08 \mathrm{~g} \mathrm{Zn}\left(\mathrm{NO}_{3}\right)_{2} \cdot 6 \mathrm{H}_{2} \mathrm{O}$ were used as precursors, while for $x=0.75$ samples, $0.73 \mathrm{~g}$ of $\mathrm{Ni}\left(\mathrm{NO}_{3}\right)_{2} \cdot 6 \mathrm{H}_{2} \mathrm{O}$ and $2.23 \mathrm{~g} \mathrm{Zn}\left(\mathrm{NO}_{3}\right)_{2} \cdot 6 \mathrm{H}_{2} \mathrm{O}$ were used.

\subsection{Characterization methods}

The X-ray diffractograms of the auto-combustion powders were recorded using an X-ray diffractometer (D8 Advance, Brucker, Germany), equipped with a $\mathrm{CuK} \alpha$ radiation source $(\lambda=1.5406 \AA)$ and the crystallite size $(D)$ is calculated from X-ray line broadening of the (311) diffraction peak using the well-known Scherrer relation

$$
D=\frac{0.9 \lambda}{\beta \cos \theta},
$$

where $\beta$ is the full-width at half-maxima of the strongest intensity diffraction peak (311), $\lambda$ the wavelength of the radiation, and $\theta$ the angle of the strongest characteristic peak. X-ray density $\left(D_{\mathrm{X}}\right)$ was calculated using

$$
D_{\mathrm{X}}=\frac{8 M}{N a^{3}},
$$

where $M$ is the molecular weight, $N$ Avogadro's number and $a$ the lattice constant. The surface morphology and elemental detection of the powders were examined with a scanning electron microscope (SEM), Ametek model XL30 Lab 6. The Raman spectra were obtained using a LabRAM HR (Olympus BX41) visible single spectrometer equipped by a microscope and a Peltier-cooled CCD detector. The $633 \mathrm{~nm} \mathrm{He}-\mathrm{Ne}$ laser line was used for excitation. The power was adjusted using a set of neutral filters. The spectral slit width at the conditions used was $1 \mathrm{~cm}^{-1}$. The laser beam was focused on the powders pressed on a glass surface by an $\times 50$ long working distance objective. The acquisition time for all samples was $60 \mathrm{~s}(\times 2-$ times per scan) for all optical excitation intensities. The Raman measurements were performed at room temperature and atmospheric pressure. The magnetic characterizations were carried out with a VSM (Lake Shore cryotronics-7400 series) under the applied field of $\pm 20,000 \mathrm{G}$ at room temperature.

\section{Results and discussion}

\subsection{Combustion reaction}

In order to synthesize crystalline $\mathrm{Ni}_{1-x} \mathrm{Zn}_{x} \mathrm{Fe}_{2} \mathrm{O}_{4}$ MNPs with no further heat treatment, to avoid sintering of the 
MNPs, the enthalpy or flame temperature was increased by using glycine with a fuel-rich composition. The possible combustion reaction is

$$
\begin{aligned}
1- & x \mathrm{Ni}\left(\mathrm{NO}_{3}\right)_{2} \cdot 6 \mathrm{H}_{2} \mathrm{O}+x \mathrm{Zn}\left(\mathrm{NO}_{3}\right)_{2} \cdot 6 \mathrm{H}_{2} \mathrm{O} \\
& +2 \mathrm{Fe}\left(\mathrm{NO}_{3}\right)_{3} \cdot 9 \mathrm{H}_{2} \mathrm{O}+6.66 \mathrm{C}_{2} \mathrm{H}_{5} \mathrm{NO}_{2}+4.99 \mathrm{O}_{2} \\
& \rightarrow \mathrm{Ni}_{1-x} \mathrm{Zn}_{x} \mathrm{Fe}_{2} \mathrm{O}_{4}+13.32 \mathrm{CO}_{2} \uparrow+40.65 \mathrm{H}_{2} \mathrm{O} \uparrow \\
& +7.33 \mathrm{~N}_{2} \uparrow,
\end{aligned}
$$

where $x=0.65,0.7$ and 0.75 . The precursor mixtures resulted in a dark red solution and the combustion types were flamy combustion. Combusted products resulted in brown powders with some black patches dotting it. This might be as a result of the unreacted glycine being a fuelrich composition. After heating in the oven at $200^{\circ} \mathrm{C}$ for $12 \mathrm{~h}$, brown powder resulted with no black patches which were grounded and used for further characterizations.

\subsection{Phase formation and structural analysis}

The powder X-ray patterns recorded for the samples of $\mathrm{Ni}_{1-x} \mathrm{Zn}_{x} \mathrm{Fe}_{2} \mathrm{O}_{4}$ are shown in figure 1 . They are all consistent with the standard pattern cubic spinel structure of bulk $\mathrm{NiFe}_{2} \mathrm{O}_{4}$ (JCPDS card no. 10-0325) and traces of secondary haematite $\left(\alpha-\mathrm{Fe}_{2} \mathrm{O}_{3}\right)$ phase were observed. Secondary haematite phases were also observed in the urea-assisted combustion synthesis of $\mathrm{Ni}_{1-x} \mathrm{Zn}_{x} \mathrm{Fe}_{2} \mathrm{O}_{4}{ }^{21}$ and sintering temperature of $1200^{\circ} \mathrm{C}$ was required to obtain good crystalline phase and remove the haematite phase from the urea-assisted combustion synthesis of

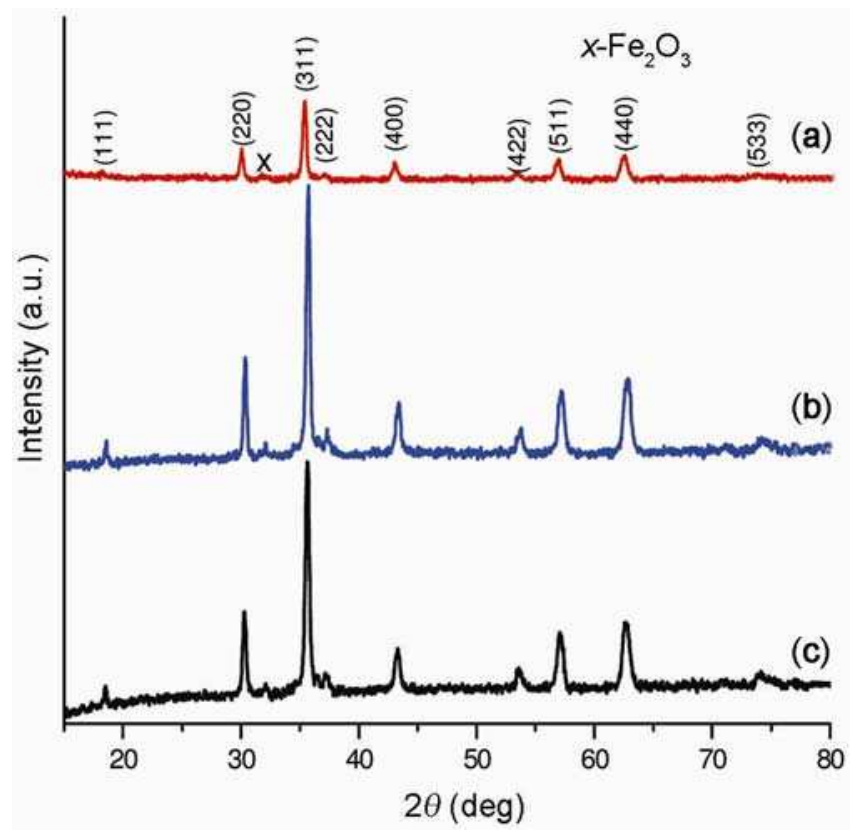

Figure 1. $\mathrm{X}$-ray diffraction patterns of $\mathrm{Ni}_{1-x} \mathrm{Zn}_{x} \mathrm{Fe}_{2} \mathrm{O}_{4}$ samples: (a) $x=0.65$, (b) $x=0.7$ and (c) $x=0.75$.
$\mathrm{Ni}_{0.5} \mathrm{Zn}_{0.5} \mathrm{Fe}_{2} \mathrm{O}_{4}{ }^{22}$ and the citrate-assisted combustion synthesis of $\mathrm{Ni}_{1-x} \mathrm{Zn}_{x} \mathrm{Fe}_{2} \mathrm{O}_{4}{ }^{9,10}$ The diffractogram exhibits sharp lines, which indicates that the sample has high crystallinity. This results show that using the glycine fuel-rich composition in the solution combustion synthesis of $\mathrm{Ni}_{1-x} \mathrm{Zn}_{x} \mathrm{Fe}_{2} \mathrm{O}_{4}$ without any further heat treatment at high temperatures is sufficient in the formation of the spinel ferrite phase. The X-ray patterns of $\mathrm{Ni}_{0.3} \mathrm{Zn}_{0.7} \mathrm{Fe}_{2} \mathrm{O}_{4}$ (figure $1 \mathrm{~b}$ ) recorded the sharpest and most intense XRD reflections compared with the other two diffraction patterns, indicating the highest crystallinity, while the X-ray patterns of $\mathrm{Ni}_{0.35} \mathrm{Zn}_{0.65} \mathrm{Fe}_{2} \mathrm{O}_{4}$ (figure 1a) recorded the lowest. The estimated values of various structural properties of $\mathrm{Ni}_{1-x} \mathrm{Zn}_{x} \mathrm{Fe}_{2} \mathrm{O}_{4}$ MNPs are given in table 1. From Scherrer's formula, it was found that all the samples obtained are nanocrystalline with sizes ranging between 54 and $56 \mathrm{~nm}$. Lattice constant decreased in $\mathrm{Ni}_{0.3} \mathrm{Zn}_{0.7}$ $\mathrm{Fe}_{2} \mathrm{O}_{4}$ and increased in $\mathrm{Ni}_{0.25} \mathrm{Zn}_{0.75} \mathrm{Fe}_{2} \mathrm{O}_{4}$. The unit cell volume which is linearly affected by the lattice constant expectedly followed the same trend. In $\mathrm{Ni}_{1-x} \mathrm{Zn}_{x} \mathrm{Fe}_{2} \mathrm{O}_{4}$, the smaller ionic radius of $\mathrm{Ni}^{2+}(0.69 \AA)$ and $\mathrm{Fe}^{3+}(0.60 \AA)$ ions are replaced by the larger $\mathrm{Zn}^{2+}(0.74 \AA)$ ions with all the ionic radii having a coordination number of six. ${ }^{23}$ Hence, it was expected that the lattice constant would increase because of expansion of unit cell dimension with the increase in the amounts of $\mathrm{Zn}^{2+}$ in obedience to Vergard's Law. However, the X-ray density $\left(D_{\mathrm{X}}\right)$ value was lowest in $\mathrm{Ni}_{0.35} \mathrm{Zn}_{0.65} \mathrm{Fe}_{2} \mathrm{O}_{4}$ (the sample with the least $\mathrm{Zn}$ content) which was in line with this calculation. The calculated $D_{\mathrm{X}}$ value for $\mathrm{Ni}_{0.3} \mathrm{Zn}_{0.7} \mathrm{Fe}_{2} \mathrm{O}_{4}$ sample (with the lowest lattice constant value) was the highest of all samples. This is also in line with the formula for calculating $D_{\mathrm{X}}$ (equation 2), which shows an inverse relationship between $D_{\mathrm{X}}$ and lattice constant. The same inverse variation of $D_{\mathrm{X}}$ with lattice constant has also been recorded in $\mathrm{Co}_{1-x} \mathrm{Mn}_{x} \mathrm{Fe}_{2} \mathrm{O}_{4}$ system. ${ }^{7}$

\subsection{Raman studies}

Room temperature Raman spectra of auto-combusted powders were recorded in the range of $0-1000 \mathrm{~cm}^{-1}$, as shown in figure 2. The popularity of Raman spectroscopy in the investigation of oxides is increasing because of its utility to probe local disorder. ${ }^{24}$ The short-range disorder in oxygen octahedra induced by Jahn-Teller distortion and other interactions can be effectively probed by Raman spectroscopy, which makes it a very versatile tool. $^{25}$ The Raman features are assigned to the vibrational modes from the nanoparticles crystalline structure. $\mathrm{NiFe}_{2} \mathrm{O}_{4}$ crystallizes with inverse spinel structure, ${ }^{26}$ described by the face-centred cubic (FCC) space group Fd-3m (no. $227, Z=8$ ). In this structure the tetrahedral A-sites (8a) are occupied by half of the $\mathrm{Fe}^{3+}$ cations, whereas the rest of the $\mathrm{Fe}^{3+}$ and $\mathrm{Ni}^{2+}$ cations are distributed over the octahedral B-sites (16d). ${ }^{27}$ According to the space group symmetry and factor group analysis, five Raman active 
Table 1. Structural properties of $\mathrm{Ni}_{1-x} \mathrm{Zn}_{x} \mathrm{Fe}_{2} \mathrm{O}_{4}$ MNPs: (a) $x=0.65$, (b) $x=0.70$ and (c) $x=0.75$.

\begin{tabular}{lcccc}
\hline $\begin{array}{l}\text { Zn conc. } \\
\text { ‘ } x\end{array}$ & $\begin{array}{c}\text { Crystallite size, } \\
D(\mathrm{~nm})\end{array}$ & $\begin{array}{c}\text { Lattice constant, } \\
a(\mathrm{~nm})\end{array}$ & $\begin{array}{c}\text { Unit cell volume, } \\
V\left(\mathrm{~nm}^{3}\right)\end{array}$ & $\begin{array}{c}\text { X-ray density, } \\
D_{\mathrm{X}}\left(\mathrm{g} \mathrm{cm}^{-3}\right)\end{array}$ \\
\hline 0.65 & 56 & 0.841 & 0.595 & 5.331 \\
0.70 & 55 & 0.833 & 0.578 & 5.495 \\
0.75 & 54 & 0.835 & 0.582 & 5.465 \\
\hline
\end{tabular}

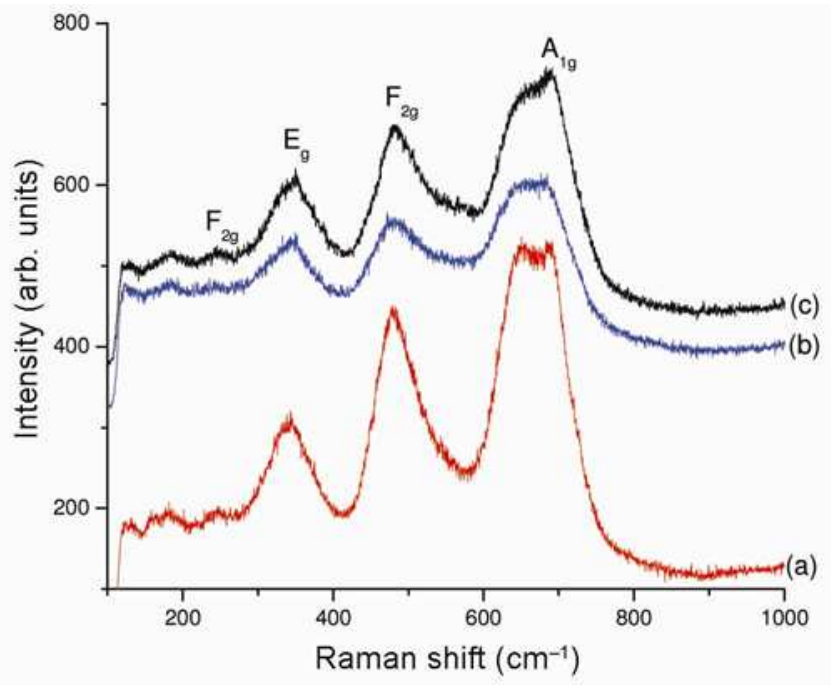

Figure 2. Raman spectra of $\mathrm{Ni}_{1-x} \mathrm{Zn}_{x} \mathrm{Fe}_{2} \mathrm{O}_{4}$ samples: (a) $x=0.65$, (b) $x=0.7$ and (c) $x=0.75$.

internal modes such as $\mathrm{A}_{1 \mathrm{~g}}, \mathrm{E}_{\mathrm{g}}$ and $3 \mathrm{~F}_{2 \mathrm{~g}}$ modes are predicted. ${ }^{24}$ In nickel-zinc ferrite, $\mathrm{Zn}^{2+}$ ions are known to occupy the tetrahedral (A) site. The $\mathrm{Zn}^{2+}$ ion has a larger ionic radius than $\mathrm{Ni}^{2+}$ ion and is expected to increase the structural disorder of the oxygen sublattice. It can be seen from the Raman spectra that there is broadening of the spectra and decrease in intensity with an increase in zinc substitution. Also, all the samples gave broad $\mathrm{A}_{1 \mathrm{~g}}$ vibrational modes. This mode has both been attributed to order-disorder effect ${ }^{28}$ and the substitution of the $\mathrm{Fe}^{3+}$ ions by $\mathrm{Zn}^{2+}$ ions in the tetrahedral sites. It can be considered from the results that the vibrational modes show tetrahedral and octahedral sites in the structure of nickelzinc ferrite with $\mathrm{Zn}^{2+}$ ions displacing $\mathrm{Fe}^{3+}$ ions from the tetrahedral site. The experimentally obtained Raman modes are consistent with those of previously reported crystalline $\mathrm{Ni}_{0.75} \mathrm{Zn}_{0.25} \mathrm{Fe}_{2} \mathrm{O}_{4}{ }^{27}$

\subsection{Morphological and chemical composition analysis}

The SEM micrographs of $\mathrm{Ni}_{1-x} \mathrm{Zn}_{x} \mathrm{Fe}_{2} \mathrm{O}_{4}(x=0.65,0.70$ and 0.75 ) are shown in figure 3 . The images of each sample powder were taken at two different magnifications $-1000 \times\left(\right.$ figure $3 \mathrm{a}^{\mathrm{I}}-\mathrm{c}^{\mathrm{I}}$ ) and $30,000 \times\left(\right.$ figure $\left.3 \mathrm{a}^{\mathrm{II}}-\mathrm{c}^{\mathrm{II}}\right)$. It can be seen that all the samples (figure $3 a^{I}-c^{I}$ ) have voids and pores (which decreased with the increase in the concentration of $\mathrm{Zn}^{2+}$ ) and can be attributed to the release of large amount of gases during the combustion process. A decrease in porosity with the increase in the concentration of $\mathrm{Zn}^{2+}$ in $\mathrm{Ni}-\mathrm{Zn}$ ferrite systems have also been reported. ${ }^{9}$ Densification of the powders with the increase in the concentration of $\mathrm{Zn}^{2+}$ can also be seen in figure $3 \mathrm{a}^{\mathrm{I}}-\mathrm{c}^{\mathrm{I}}$. The addition of zinc to ferrites results in the densification of the material. ${ }^{9,29}$ Combustion flame temperature was found to increase with the increase in the concentration of $\mathrm{Zn}^{2+}$ in $\mathrm{Ni}_{1-x} \mathrm{Zn}_{x} \mathrm{Fe}_{2} \mathrm{O}_{4}$ system. ${ }^{21}$ It was explained that the changes in the systems' compositions in response to increasing concentrations of $\mathrm{Zn}^{2+}$ caused the combustion flame temperature to increase, thereby favouring agglomeration and pre-sintering. This explanation can also be extended to the remarkable changes in microstructure, regarding density and porosity, observed in response to increasing concentrations of $\mathrm{Zn}^{2+}$ in this study. In figure $3 b^{\text {II }}-c^{\text {II }}$, agglomerated oval-shaped morphology was observed along with a few semi-spherulitic shapes which clearly differed from the smaller, irregular, and agglomerated morphology seen in figure $3 \mathrm{a}^{\mathrm{II}}$. This might be interpreted as the formation of a poorer crystalline ferrite phase of $\mathrm{Ni}_{0.35} \mathrm{Zn}_{0.65} \mathrm{Fe}_{2} \mathrm{O}_{4}$, corroborating the XRD results which recorded the lowest intensity XRD peaks compared with other samples.

The compositional analyses of the nanocrystalline $\mathrm{Ni}_{1-x}$ $\mathrm{Zn}_{x} \mathrm{Fe}_{2} \mathrm{O}_{4}(x=0.65,0.70$ and 0.75$)$ samples were carried out by EDAX and they are shown in figure $4 \mathrm{a}-\mathrm{c}$. From the EDAX results, the presences of $\mathrm{Ni}, \mathrm{Zn}, \mathrm{Fe}$ and $\mathrm{O}$ in the samples were confirmed with no impurity present and the compositional molar ratio of $\mathrm{Ni}$ and $\mathrm{Zn}$ to $\mathrm{Fe}$ were found to be close to 0.5 (table 2).

\subsection{Magnetic studies}

Figure 5 shows the magnetic hysteresis curves of $\mathrm{Ni}_{1-x} \mathrm{Zn}_{x} \mathrm{Fe}_{2} \mathrm{O}_{4}$ samples recorded at room temperature. The effects of $\mathrm{Zn}$ doping on the magnetic properties are given in table $3 . \mathrm{NiFe}_{2} \mathrm{O}_{4}$ exhibits ferrimagnetism originating from the magnetic moment of anti-parallel spins between $\mathrm{Fe}^{3+}$ at the tetrahedral sites and $\mathrm{Ni}^{2+}$ at the octahedral sites. ${ }^{30}$ The saturation magnetization $\left(M_{\mathrm{s}}\right)$ and remanence magnetization $\left(M_{\mathrm{r}}\right)$ of $\mathrm{Ni}_{0.35} \mathrm{Zn}_{0.65} \mathrm{Fe}_{2} \mathrm{O}_{4}$ sample is 36 and $22.5 \mathrm{emu} \mathrm{g}^{-1}$, respectively, while $M_{\mathrm{s}}$ and $M_{\mathrm{r}}$ of $\mathrm{Ni}_{0.25} \mathrm{Zn}_{0.75} \mathrm{Fe}_{2} \mathrm{O}_{4}$ sample is 25 and 15 emu g ${ }^{-1}$, respectively. 

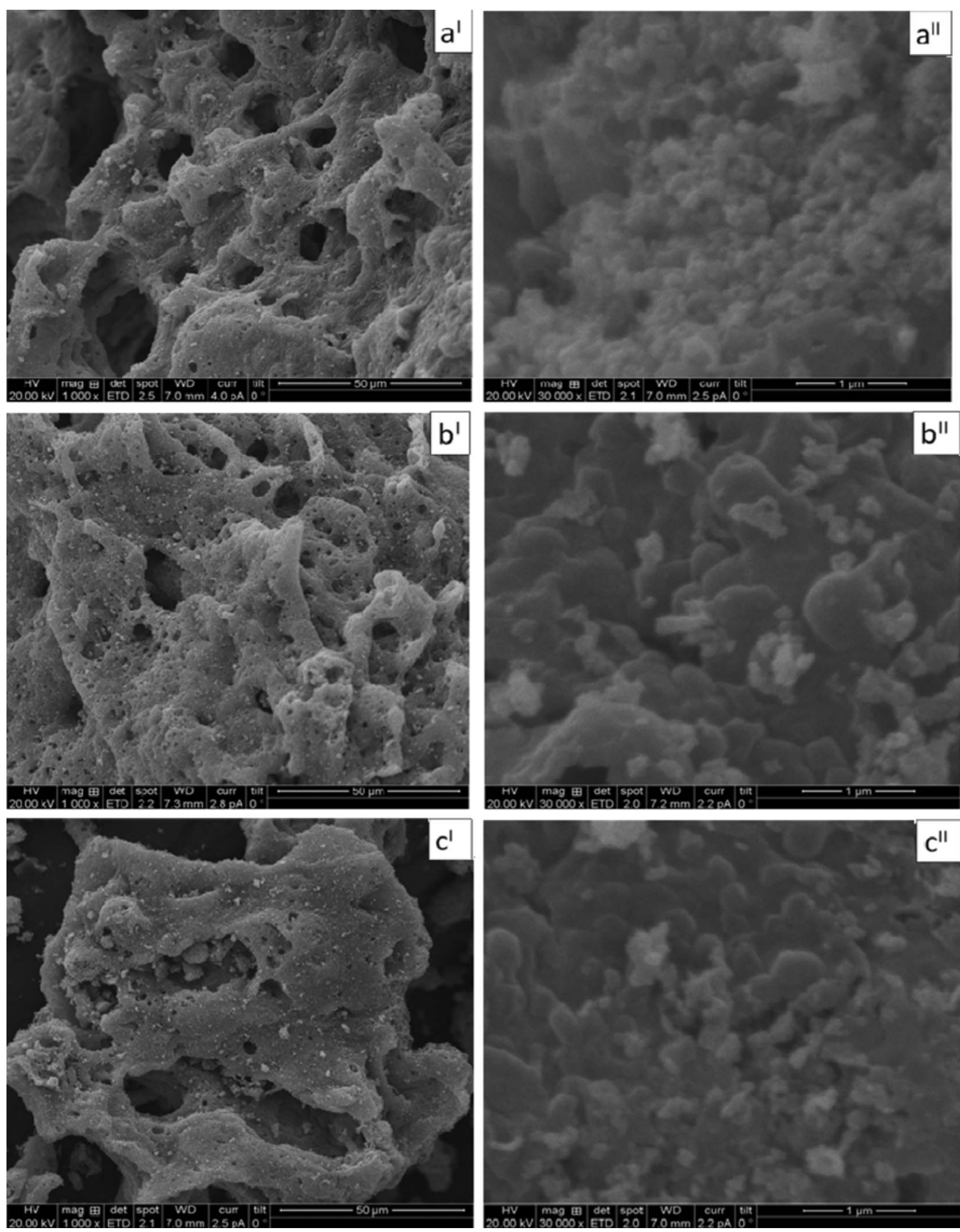

Figure 3. SEM micrographs of $\mathrm{Ni}_{1-x} \mathrm{Zn}_{x} \mathrm{Fe}_{2} \mathrm{O}_{4}$ samples: $\left(\mathbf{a}^{\mathrm{I} \& \mathrm{II}}\right) x=0.65,\left(\mathbf{b}^{\mathrm{I} \& \mathrm{II}}\right) x=0.7$ and $\left(\mathbf{c}^{\mathrm{I} \& \mathrm{II}}\right) x=0.75$.

Table 2. Compositional concentration (\%) of the constituent elements of $\mathrm{Ni}_{1-x} \mathrm{Zn}_{x} \mathrm{Fe}_{2} \mathrm{O}_{4}$ ferrite system by EDAX.

\begin{tabular}{lcccc}
\hline$x$ & $\mathrm{Ni}$ & $\mathrm{Zn}$ & $\mathrm{Fe}$ & $\mathrm{O}$ \\
\hline 0.65 & 4.29 & 10.20 & 30.38 & 55.13 \\
0.70 & 2.70 & 11.70 & 30.61 & 54.99 \\
0.75 & 2.66 & 12.33 & 30.41 & 54.60 \\
\hline
\end{tabular}

The results show that the $M_{\mathrm{S}}$ and $M_{\mathrm{r}}$ decreases with the increase in the zinc content. A marked reduction in $M_{\mathrm{s}}$ has been reported for $\mathrm{Ni}_{1-x} \mathrm{Zn}_{x} \mathrm{Fe}_{2} \mathrm{O}_{4}$, as the concentration of $\mathrm{Zn}^{2+}$ was increased from $x=0.5$ to $0.7{ }^{21}$ This behaviour was attributed to the spin canting effect that occurs when $\mathrm{BB}$ interactions are comparable to $\mathrm{AB}$ interactions. ${ }^{31}$ It is important to state that due to antiparallel 

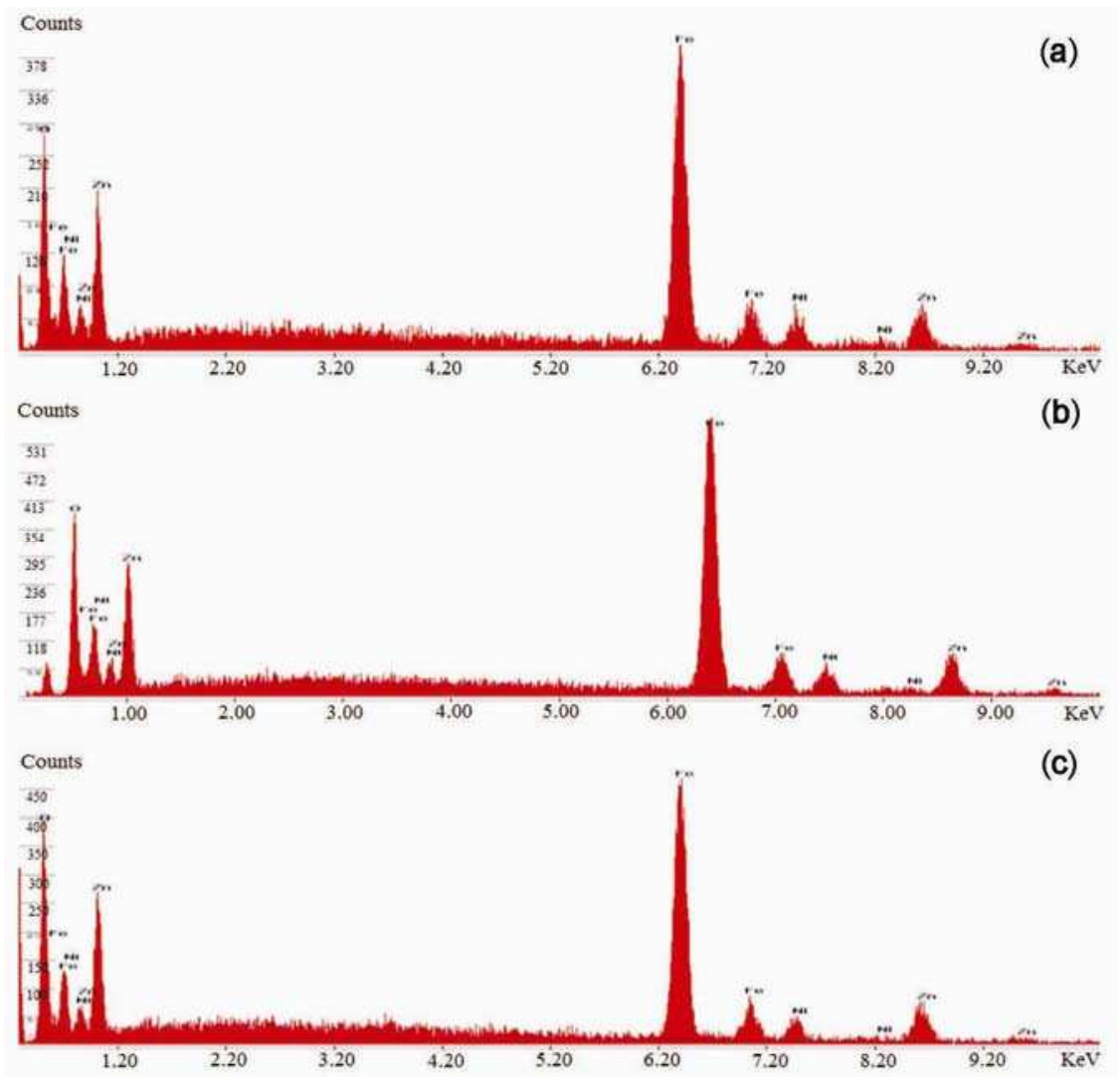

Figure 4. EDAX spectra of $\mathrm{Ni}_{1-x} \mathrm{Zn}_{x} \mathrm{Fe}_{2} \mathrm{O}_{4}$ samples: (a) $x=0.65$, (b) $x=0.7$ and (c) $x=0.75$.

Table 3. Effects of $\mathrm{Zn}$ doping on the magnetic properties of $\mathrm{Ni}_{1-x} \mathrm{Zn}_{x} \mathrm{Fe}_{2} \mathrm{O}_{4}$ MNPs: (a) $x=0.65$, (b) $x=0.70$ and (c) $x=0.75$.

\begin{tabular}{lcccc}
\hline $\begin{array}{l}\text { Zn conc. } \\
\text { ‘ } x\end{array}$ & $\begin{array}{c}\text { Saturation magnetization, } \\
M_{\mathrm{s}}\left(\mathrm{emu} \mathrm{g}^{-1}\right)\end{array}$ & $\begin{array}{c}\text { Remanence magnetization, } \\
M_{\mathrm{r}}\left(\mathrm{emu} \mathrm{g}^{-1}\right)\end{array}$ & $\begin{array}{c}\text { Coercivity, } \\
H_{\mathrm{c}}(\mathrm{Gauss})\end{array}$ & $M_{\mathrm{r}} / M_{\mathrm{s}}$ \\
\hline 0.65 & 36 & 22.5 & 239 & 0.63 \\
0.70 & 32 & 19.0 & 224 & 0.59 \\
0.75 & 25 & 15.0 & 234 & 0.60 \\
\hline
\end{tabular}

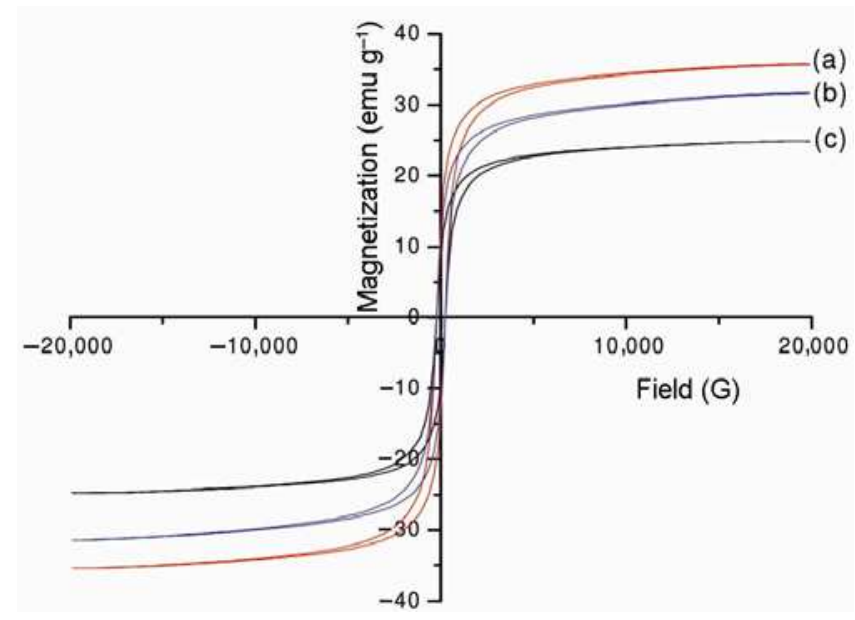

Figure 5. Magnetic hysteresis curves of $\mathrm{Ni}_{1-x} \mathrm{Zn}_{x} \mathrm{Fe}_{2} \mathrm{O}_{4}$ MNPs measured at room temperature for (a) $x=0.65$, (b) $x=0.70$ and (c) $x=0.75$. coupling between the A-sites and B-sites in spinel structured materials, the net magnetization $(M)$ is given by $M=\sum M_{\text {Bsites }}-\sum M_{\text {Asites. }} \mathrm{Zn}^{2+}$ ions are known to occupy the tetrahedral (A) site; $\mathrm{Ni}^{2+}$ ions have a preference for the octahedral (B) site while the $\mathrm{Fe}^{3+}$ ions are distributed over both sites in mixed $\mathrm{Ni}-\mathrm{Zn}$ ferrites. When the concentration of $\mathrm{Fe}^{3+}$ ions in the A sublattice is diluted by low concentrations of diamagnetic substitutions (such as $\mathrm{Zn}^{2+}$ ions), the net magnetization increases. ${ }^{32}$ However, magnetization decreases at higher levels of doping as seen in this study with $x=0.65-0.75$. The reason for this is that low $\mathrm{Zn}$ concentrations reduce the number of spins occupying the A sublattices, causing the net magnetization to increase. As the $\mathrm{Zn}$ content increases, the exchange interactions are weakened and the $\mathrm{B}$ spins are no longer held rigidly parallel to the few remaining $A$ spins. The decrease in the B-sublattice moment, interpreted as a spin departure from colinearity, causes the 


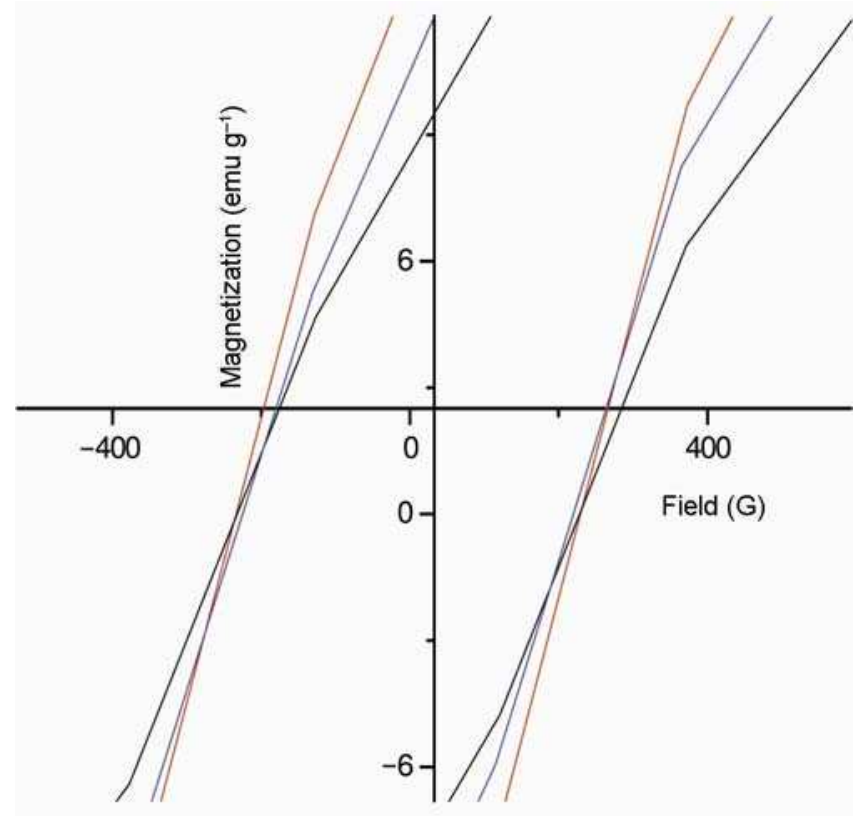

Figure 6. Magnified view of hysteresis loops of $\mathrm{Ni}_{1-x} \mathrm{Zn}_{x}$ $\mathrm{Fe}_{2} \mathrm{O}_{4}$ samples to show their ferrimagnetism.

effect known as canting. ${ }^{21}$ Also, the decrease in $M_{\mathrm{s}}$ with the increase in the zinc content can be explained from the crystallite sizes of the samples shown in table 1 . The crystallite sizes (and by extension, the $M_{\mathrm{s}}$ ) of the samples clearly show a slight decrease with the increase in the zinc content. It is known that $M_{\mathrm{s}}$ gradually increases with crystallite size, ${ }^{33,34}$ which might be due to decreased domain walls displacement as the crystallite sizes increases in the multi-domain range. ${ }^{35}$ The $M_{\mathrm{r}}$ is known to vary linearly with $M_{\mathrm{s}}$ in ferromagnetic (or ferrimagnetic) materials as observed in this study.

The variation in coercivity $\left(H_{\mathrm{c}}\right)$ with $\mathrm{Zn}$ doping is clearly observed in the magnified view of the hysteresis curves in figure 6. It shows hysteresis loops that are typical of soft ferrimagnetic materials. The $H_{\mathrm{c}}$ of $\mathrm{Ni}_{0.35} \mathrm{Zn}_{0.65} \mathrm{Fe}_{2} \mathrm{O}_{4}$ sample recorded the highest values, while $\mathrm{Ni}_{0.3} \mathrm{Zn}_{0.7} \mathrm{Fe}_{2} \mathrm{O}_{4}$ sample recorded the lowest. It can be seen that $H_{\mathrm{c}}$ decreased in $x=0.7$ and increased in $x=0.75$. The $H_{\mathrm{c}}$ of the samples shows a nonlinear relationship with zinc doping and the crystallite size. According to literature, ${ }^{7,36-38}$ there is no firm relationship between $H_{\mathrm{c}}$ and grain size thereby establishing that the influence of the crystallite size of different alloy systems on $H_{\mathrm{c}}$ is undetectable. The squareness ratio $\left(M_{\mathrm{r}} / M_{\mathrm{s}}\right)$ values of all samples were higher than 0.5 , highlighting the potential applications of these materials for recording medium. These results show that the magnetic properties of the material are dependent on the amount of $\mathrm{Zn}$ present. All samples recorded a fairly high saturation magnetization (25$36 \mathrm{emu} \mathrm{g}^{-1}$ ) with the increase in $M_{\mathrm{s}}$ and $M_{\mathrm{r}}$ with the decrease in $x$ (Zn content).

\section{Conclusion}

A fuel-rich glycine-nitrate mixture in the combustion synthesis of $\mathrm{Ni}_{1-x} \mathrm{Zn}_{x} \mathrm{Fe}_{2} \mathrm{O}_{4}$ was sufficient for the formation of pure nanocrystalline spinel ferrite phase without any further heat treatment at high temperatures. Raman spectra show tetrahedral and octahedral sites in the structure of $\mathrm{Ni}_{1-x} \mathrm{Zn}_{x} \mathrm{Fe}_{2} \mathrm{O}_{4}$ and also imply the doping of $\mathrm{Zn}^{2+}$ and displacement of $\mathrm{Fe}^{3+}$ ions from the tetrahedral site. EDAX showed that the samples were close to the nominal compositions. The magnetic measurement shows that the saturation magnetization and remanence magnetization decreases with the increase in the zinc content, while coercivity showed a nonlinear relationship. The squareness ratio $\left(M_{\mathrm{r}} / M_{\mathrm{s}}\right)$ values of all samples were higher than 0.5 , highlighting the potential applications of these materials for recording medium.

\section{Acknowledgements}

This work would not have been possible without the visiting research grant given to $\mathrm{Mr}$ Ehi-Eromosele C.O. by the International Centre for Materials Science, Jawarharlal Nehru Centre for Advanced Scientific Research, Bangalore, India. We would like to thank Professor Chandra Srivastava and his student, Mr Mahander Singh, Department of Materials Engineering, Indian Institute of Science (IISc), Bangalore, for helping with the VSM analysis. The corresponding author would also thank Mr Olu Emmanuel Femi for introducing him to the VSM facility at IISc.

\section{References}

1. Sugimoto M 1999 J. Am. Ceram. Soc. 82269

2. Lazarević Z Ž, Jovalekić Č, Sekulić D, Slankamenac M, Romčević M, Milutinović A and Romčević N Ž 2012 Sci. Sinter. 44331

3. Sivakumar P, Ramesh R, Ramanand A, Ponnusamy S and Muthamizhchelvan C 2011 Mater. Res. Bull. 462208

4. Sivakumar P, Ramesh R, Ramanand A, Ponnusamy S and Muthamizhchelvan C 2011 Mater. Res. Bull. 462204

5. Kasapoglu N, Baykal A, Toprak M S, Koseoglu Y and Bayrakdar H 2007 Turk. J. Chem. 31659

6. Sepelak V, Baabe K, Mienert K, Schultze K, Krumeich F, Litterst F J and Becker K D 2003 J. Magn. Magn. Mater. 257377

7. Salunkhe A B, Khot V M, Phadatare M R, Thorat N D, Joshi R S, Yadav H M and Pawar S H 2014 J. Magn. Magn. Mater. 35291

8. Morrison S A, Cahill C L, Carpenter E E, Calvin S, Swaminathan R, McHenry M E and Harris V G 2004 J. Appl. Phys. 956392

9. Krishna K R, Kumar K V and Ravinder D $2012 A d v$. Mater. Phys. Chem. 2185

10. Vermaa A, Goela T C, Mendirattaa R G and Kishan P 2000 J. Magn. Magn. Mater. 20813 
11. Vermaa A, Goela T C, Mendirattaa R G and Gupta R G 1999 J. Magn. Magn. Mater. 192271

12. Mohan G R, Ravinder D, Reddy A V R and Boyanov B S 1999 Mater. Lett. 4039

13. Ajmal M and Maqsood A 2007 Mater. Sci. Eng. B 139164

14. Sileo E E, Rotelo R and Jacobo S E 2002 Physica B: Condens. Matter $\mathbf{3 2 0} 257$

15. Costa A C F M, Tortella E, Morelli M R and Kiminami R H G A 2003 J. Magn. Magn. Mater. 256174

16. Cabanas A and Poliakoff M 2001 J. Mater. Chem. 111408

17. Song H J, Oh J H, Choi S C and Lee J C 2002 Phys. Status Solidi A 189849

18. Akther Hossain A K M, Mahmud S T, Seki M, Kawai T and Tabata H 2007 J. Magn. Magn. Mater. 312210

19. Deng H, Chen H and Li H 2007 Mater. Chem. Phys. 101 509

20. Costa A C M, Tortella E, Morelli M R, Kaufman M and Kiminami R H G A 2002 J. Mater. Sci. 373569

21. Costa A C M, Silva V J, Cornejo D R, Morelli M R, Kiminami R H and Gama L 2008 J. Magn. Magn. Mater. 320 e370

22. Costa A C M, Diniz A P, Silva V J, Kiminami R H, Cornejo D R, Gama A M, Rezende M C and Gama L 2009 J. Alloys Compd. 483563

23. Shannon R D 1976 Acta Crystallogr. 32751

24. Ahlawat A and Sathe V G 2011 J. Raman Spectrosc. 42 1087

25. Dubey A, Sathe V G and Rawat R 2008 J. Appl. Phys. 104 113530
26. Carta D, Casula M F, Falqui A, Loche D, Mountjoy G, Sangregorio C and Corrias A 2009 J. Phys. Chem. 113 8606

27. Ivanov V G, Abrashev M V, Iliev M N, Gospodinov M M J and Aroyo M M I 2010 Phys. Rev. B: Condens. Matter 82 024104

28. Wang Z, Lazor P, Saxena S K and O'Neil H S C 2002 Mater. Res. Bull. 371589

29. Kishan P, Sagar D R and Swarup P 1985 J. Less Common Met. 108345

30. Kambale R C, Shaikh P A, Kamble S S and Kolekar Y D 2009 J. Alloys Compd. 478599

31. Costa A C F M 2002 PhD Thesis (Sao Paulos, Brazil: Department of Engineering of Materials, Federal University of Sao Carlos)

32. Bercoff P G and Bertorello H R 2000 J. Magn. Magn. Mater. 21356

33. $\mathrm{Hu}$ P, Yang H, Pan D, Wang H, Tian J, Zhang S, Wang X and Volinsky A A 2010 J. Magn. Magn. Mater. 322 173

34. Kumar E R, Jayaprakash R and Kumar S 2014 Mater. Sci. Semiconduct. Process. 17173

35. Zhao L, Yang H, Yu L, Cui Y, Zhao X, Zou B and Feng S 2006 J. Magn. Magn. Mater. 301445

36. Shirsath S E, Jadhav S S, Toksha B G, Patange S M and Jadhav K M 2011 J. Appl. Phys. 110013914

37. Herzer G 1990 IEEE Trans. Magn. 261397

38. Zeng Q, Baker I, McCreary V and Yan Z 2007 Mater. Res. Soc. Symp. 980 0980-II06-09 